\title{
Potensi Environmental DNA (e-DNA) Untuk Pemantauan dan Konservasi Keanekaragaman Hayati
}

\section{(The Potential of Environmental DNA (e-DNA) for Monitoring and Biodiversity Conservation)}

\author{
Siti Marfuah ${ }^{*}$, Beivy Jonathan Kolondam, Trina Ekawati Tallei \\ Program Studi Biologi, Jurusan Biologi FMIPA UNSRAT Manado, 95115 \\ *Email korespondensi: 17101102013@student.unsrat.ac.id
}

(Article History: Received January 6, 2021; Revised February 12, 2021; Accepted February 28, 2021)

\begin{abstract}
ABSTRAK
Hilangnya spesies dan adanya spesies invasif dalam suatu habitat dapat menjadi ancaman bagi spesies asli dalam satu ekosistem. Untuk itu diperlukan teknik terkini yang mampu mendeteksi keberadaan suatu organisme. Salah satu teknik yang dapat mendeteksi organisme target di lingkungan secara cepat dan akurat yaitu environmental DNA (e-DNA).Tujuan dari ulasan artikel ini yaitu untuk mengeksplorasi kemampuan e-DNA secara ekogenomik untuk pemantauan dan konservasi keanekaragaman hayati. Ulasan artikel ini menggunakan data sekunder yang diperoleh dari berbagai database yang berbasis dalam jaringan. Hasil analisis memperlihatkan bahwa dengan menggunakan pendekatan e-DNA pemantauan dan konsevasi keanekaragaman hayati dapat dideteksi sesuai dengan taksonomi organisme dan penanda molekuler. Penanda molekuler Cytochrome c Oxidase subunit 1 (COI) mampu mendeteksi berbagai spesies baik langka dan invasif. Dengan demikian dapat disimpulkan bahwa pendekatan e-DNA dapat dijadikan sebagai metode untuk pemantauan dan konsevasi keanekaragaman hayati pada berbagai ekosistem.
\end{abstract}

Kata - kata kunci: environmental DNA; keanekaragaman hayati dan konservasi; penanda molekuler

The loss of species and the presence of invasive species in a habitat can be a threat to native species in an ecosystem. So we need the latest techniques that are able to detect the presence of an organism. One technique that can detect target organisms in the environment quickly and accurately is environmental DNA (e-DNA). The purpose of this review article is to explore the ecogenomic ability of $e-D N A$ for monitoring and conservation of biodiversity. This article reviews using secondary data obtained from various network-based databases. The results of the analysis show that by using the eDNA approach, monitoring and conservation of biological diversity can be detected according to the taxonomy of organisms and molecular markers. Cytochrome c Oxidase subunit 1 (COI) molecular markers are capable of detecting a variety of both rare and invasive species. Thus it can be concluded that the e-DNA approach can be used as a method for monitoring and conservation of biological diversity in various ecosystems.

Keywords: environmental DNA; biodiversity and conservation; molecular markers

\section{PENDAHULUAN}

Keanekaragaman hayati berpengaruh terhadap ekosistem yang merupakan dasar ilmu ekologi. Ekologi mampu memahami dan mendeskripsikan keadaan suatu sistem juga mengenali dinamika kompleks di dalamnya. sumbu kompleksitas terbagi atas taksonomi, spasial dan temporal (Chase et al. 2018; McGlinn et al. 2019). Asosiasi dan fungsi ekosistem yang relevan sangat dibutuhkan untuk semua ekosistem di seluruh dunia dalam memahami proses, mekanisme dan faktor yang mendasari keanekaragaman hayati, dan hilangnya keanekaragaman hayati (Altermatt et al. 2020). Perkembangan ilmu pengetahuan terhadap sumber daya biotik dan abiotik misalnya perikanan, minyak dan gas bahkan pertambangan memaksakan pengembangan teknologi dalam penilaian dan pemantauan untuk dapat di implementasi secara kooperatif berdasarkan parameter lingkungan (fisika-kimia) (Aguzzi et al. 2019). 
Ekosistem yang sangat terancam di dunia yaitu sungai, danau dan perairan laut dalam. Ekosistem air tawar termasuk yang sangat terancam oleh tekanan global seperti perubahan iklim, spesies invasif, pencemaran lingkungan, atau hilangnya habitat yang menyebabkan terdistribusinya organisme dalam ekosistem (Urban et al. 2016). Antropogenik menjadi ancaman terhadap keanekaragaman hayati yang dapat merusak jaringan dan fungsi ekologi diikuti dengan kepunahan spesies. Untuk memahami jaringan dan fungsi ekologi yang berubah saat ini ahli biologi konservasi semakin berfokus pada pengembangan teknologi non-invasif yang mampu mengidentifikasi spesies tertentu dan mengkarakterisasi komunitas biologis dalam suatu lingkungan (Valentini et al. 2016; Losapio dan Schöb, 2017; Roslin et al. 2019).

High-throughput sequencing atau dikenal dengan next-generation sequencing (NGS) merupakan teknologi terbaru dalam pembacaan sekuen DNA diantaranya whole genome sequencing, targeted sequencing, dan de novo sequencing (Roslin et al. 2019). Salah satu teknik yang dapat diterapkan untuk mendeteksi keberadaan organisme, baik dari komposisi, struktur komunitas maupun keanekaragamannya, yaitu environmental DNA (e-DNA). Sampel diperoleh langsung dari lingkungan misalnya tanah, sedimen, air atau udara yang dapat berasal dari seluruh organisme atau mikro-organisme, seperti alga atau rotifer dalam bentuk yang paling murni menggambarkan DNA yang terlepas berupa feses, lendir, sel kulit, organel, gamet atau bahkan DNA ekstraseluler (Zhang et al. 2018). Upaya konservasi saat ini banyak dikembangkan dengan menggunakan barcode DNA misalnya dalam mengidentifikasi amfibi dan reptil di Austria (Zangl et al. 2020). Berdasarkan uraian di atas, maka ulasan artikel ini bertujuan untuk membahas tentang kemampuan e-DNA secara ekogenomik yaitu interaksi antara gen dengan lingkungan untuk pemantauan dan konservasi keanekaragaman hayati.

\section{METODE}

Metode penelitan yang digunakan yaitu studi pustaka. Data-data yang digunakan merupakan data sekunder yang diperoleh dari artikel pada jurnal, buku, dan pustaka lainnya berbasis dalam jaringan pada portalportal basis data dan mesin pencari terkemuka. Penelusuran literatur menggunakan Google Scholar, ResearchGate, dan Science Direct. Katakata kunci yang diplih dalam penelusuran literatur yakni: environmental DNA, biodiversity and conservation, dan penanda molekuler. Artikel-artikel yang sesuai dengan kriteria diambil dan dikumpulkan dalam bentuk file pdf. Artikel-artikel yang dikumpulkan tersebut kemudian dianalisis dan disintesis, lalu diambil kesimpulan secara umum.

\section{HASIL DAN PEMBAHASAN}

\section{Deteksi $e-D N A$ untuk Pemantauan dan Konservasi Keanekaragaman Hayati}

Sebagian besar studi e-DNA berfokus pada deteksi spesifik spesies termasuk deteksi spesies invasif dan terancam. Deteksi dini spesies invasif sangat penting untuk mengembangkan strategi konservasi yang bertujuan melindungi keanekaragaman spesies asli. Karena kepekaan dan efektivitas biaya, teknologi e-DNA belakangan ini semakin meningkat digunakan sebagai strategi manajemen untuk memantau beberapa spesies invasif termasuk ikan seperti Ikan mas Asia di Great Lakes di Amerika Serikat dan Kanada (Jerde et al. 2013; Wittmann et al. 2014; Erickson et al. 2016; Wozney dan Wilson, 2017). Analisis e-DNA dapat menyaring ada atau tidaknya spesies langka dalam sampel air bukan hanya ikan tetapi spesies lain berkemungkinan tersaring karena memiliki materi genetik. Tentunya hal ini sangat berguna untuk memantau dan melestarikan spesies yang rentan. Selain deteksi spesies tunggal, e-DNA mampu memperkirakan kekayaan komunitas organisme target yang sangat penting untuk pengelolaan dan konservasi melalui e-DNA metabrcoding 
High troughput sequencing adalah alat yang menjanjikan dan ampuh untuk pemantauan keanekaragaman hayati diberbagai ekosistem termasuk perairan dalam hal ini spesies ikan (Shu et al. 2020).

Langkah-langkah dalam penelitian eDNA dapat dilihat pada Gambar 1. Sampel dikumpulkan dari lingkungan. Selanjutnya e-DNA dari organisme di setiap sampel diekstraksi sehingga yang tersisa adalah DNA. DNA yang diperoleh kemudian diperbanyak menggunakan teknologi PCR dan primer yang sesuai dengan organisme target. Fragmen dari primer yang digunakan lalu disekuensing menggunakan teknologi next-generation sequencing yang menunjukkan urutan basa pada untai DNA. Hasil sekuensing berupa data-data sekuens dicocokan dengan database kemudian dianalisis secara bioinformatika. Hasil analisis ini berupa taksa-taksa dari suatu sampel, mulai dari tingkatan filum sampai spesies (Schallenberg et al. 2020).

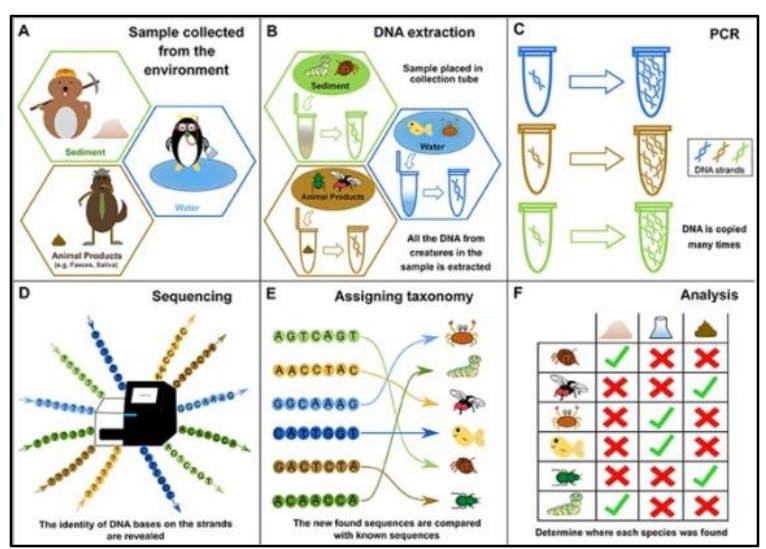

Gambar 1. Langkah-langkah dalam penelitian e-DNA (Schallenberg et al. 2020).

Deteksi spesies target meliputi reaksi rantai polimerase konvensional (cPCR), PCR kuantitatif (qPCR), atau digital droplet PCR (ddPCR) (Doi et al. 2015). Kesulitan utama yang dihadapi ekosistem laut dalam pemantauan dan konservasi keanekaragaman hayati dengan analisis molekuler adalah ketiadaan taksonomi secara umum dan terbatasnya database yang sesuai urutan penanda untuk spesies tertentu (Sinniger et al. 2016). Beberapa penemuan yang berhasil dikompilasi tentang organisme yang ditemukan sesuai dengan penanda molekuler pada lingkungan perairan dan daratan dapat dilihat pada Tabel 1.

High troughput sequencing memungkinkan pemrosesan data genomik dalam jumlah besar menggunakan perangkat portabel kecil seperti sequencer miniatur yang diproduksi oleh Oxford Nanopore. Teknologi ini seukuran stik USB yang dapat melakukan pemantauan jaringan dan fungsi ekologi yang diikuti dengan kemajuan bioinformatika (Cordier et al. 2017).

\section{Environmental-DNA untuk Konservasi Keanekaragaman Hayati}

Penerapan environmental DNA (e-DNA) dalam pemantuan keanekaragaman hayati akuatik saat ini banyak digunakan terutama e-DNA metabarcoding yang dapat mendeteksi berbagai spesies karena bersifat non-invasif, sensivitas tinggi dan hemat biaya jika dibandingkan dengan metode tradisional lainnya (Bohmann et al. 2014; Jackson et al. 2016). Penggunaan e-DNA dalam ekologi telah diidentifikasi potensinya dalam pemantauan keanekaragaman hayati skala luas untuk hewan dan tumbuhan (Taberlet et al. 2018). Kemajuan metabarcoding e-DNA menggabungkan pengambilan sampel secara acak dengan teknologi sekuensing modern yaitu next generation sequencing (NGS) (Deiner et al. 2016). Keuntungan dari penggunaan e-DNA untuk konservasi keanekaragaman hayati seperti vertebrata langka dan spesies invasif dapat dilihat pada Gambar 2.

Namun, teknik ini memiliki beberapa batasan yang harus dievaluasi dan dihindari dengan hati-hati serta diperlukan ketelitian. Adanya kontaminasi menyebabkan deteksi positif palsu yaitu tidak adanya spesies target di lingkungan tetapi DNA-nya ada, sementara kesalahan identifikasi dapat menyebabkan deteksi negatif palsu yaitu spesies target tidak terdeteksi saat berada di lingkungan, yang dapat mengubah perkiraan kekayaan dan keanekaragaman taksonomi (Cristescu dan Hebert, 2018; CalderónSanou et al. 2019). 


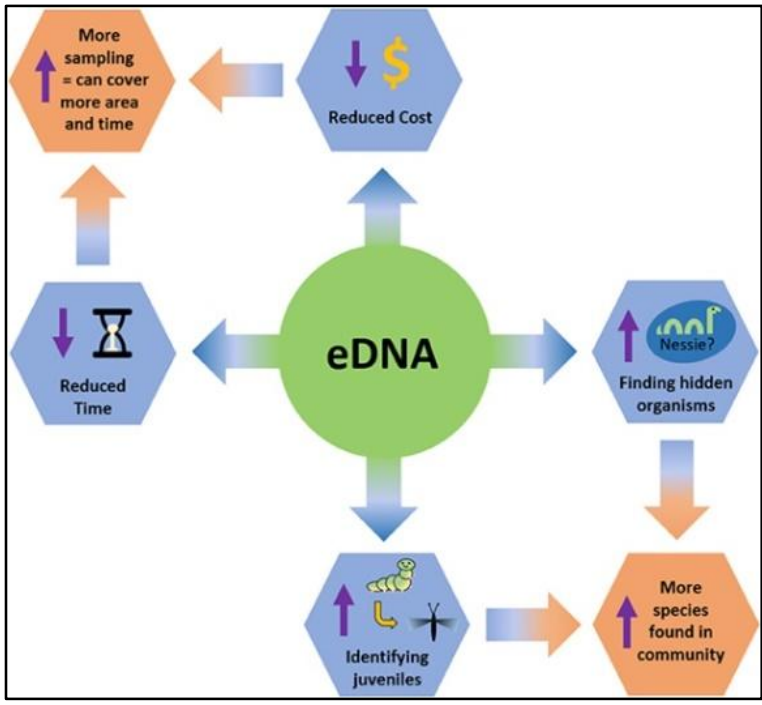

Gambar 2. Keuntungan penggunaan e-DNA untuk konservasi keanekaragaman hayati (Schallenberg et al. 2020).

\section{Keanekaragaman Hayati dalam Fungsi Ekosistem}

Biomonitoring dalam menilai kualitas keanekaragaman hayati secara tidak langsung melibatkan fungsi ekosistem. Pendekatan baru dalam ekogenomik untuk mengukur keragaman dan fungsi ekologi pada saat yang sama secara langsung dengan teknik e-DNA meliputi metabarcoding, metagenomik, dan metatranscriptomik mampu menganalisis kemunculan dan ekspresi gen fungsional, menganalisis keragaman filogenetik, dan metabolisme organisme yang berada dalam komunitas alami. Jaringan dan fungsi ekosistem yang berbeda dalam ekologi tidak hanya melibatkan perhitungan dan pengelompokkan spesies tetapi melibatkan data kelimpahan gen fungsional (Taberlet et al. 2018). Kemajuan bioinformatika memudahkan dalam menganalisis data metagenomik dan metatranscriptomik sehingga dapat dihubungkan dengan data pada lingkungan, baik secara in situ atau penginderaan jauh, untuk menghubungkan status lingkungan dan fungsi lingkungan serta proses biologis masing-masing organisme melalui ekspresi gen (Keck et al. 2017).

Tabel 1. Organisme yang ditemukan sesuai dengan penanda molekuler

\begin{tabular}{|c|c|c|c|}
\hline Klasifikasi & Genus/spesies & $\begin{array}{l}\text { Penanda } \\
\text { molekuler }\end{array}$ & Referensi \\
\hline \multirow[t]{2}{*}{ Invertebrata } & $\begin{array}{l}\text { Sabella spallanzanii } \\
\text { Styela clava }\end{array}$ & $\begin{array}{l}\text { Cytochrome } \quad c \\
\text { Oxidase } \\
\text { subunit } 1(\mathrm{COI})\end{array}$ & Wood et al. 2020 \\
\hline & $\begin{array}{l}\text { Austrominius modestus } \\
\text { Bugula neritina } \\
\text { Ficopomatus enigmatus }\end{array}$ & $\begin{array}{l}\text { Cytochrome c } \\
\text { Oxidase } \\
\text { subunit } 1 \\
\text { (COI) dan } \\
18 \mathrm{~S} \text { (nuclear } \\
\text { small subunit } \\
\text { ribosomal } \\
\text { DNA) }\end{array}$ & Holman et al. 2019 \\
\hline \multirow[t]{2}{*}{ Vertebarata } & $\begin{array}{l}\text { Puma concolor } \\
\text { Lynx rufus } \\
\text { Canis latrans } \\
\text { Urocyon } \\
\text { cinereoargenteus }\end{array}$ & $\begin{array}{l}\text { MiMammal-U } \\
\text { untuk } 12 \mathrm{~S} \\
\text { Gen mtDNA }\end{array}$ & Meyer et al. 2020 \\
\hline & $\begin{array}{l}\text { Podarcis muralis } \\
\text { Natrix helvetica }\end{array}$ & $\begin{array}{l}\text { Cytochrome c } \\
\text { Oxidase } \\
\text { subunit } 1(\mathrm{COI})\end{array}$ & Zangl et al. 2020 \\
\hline
\end{tabular}


Penanda atau primer molekuler sangat bervariasi tergantung pada tujuan deteksi DNA target. Primer khusus dirancang untuk dapat mendeteksi spesies tunggal, sedangkan primer generik dirancang untuk dapat mendeteksi taksa yang beragam melalui metabarcoding. DNA Mitokondria banyak digunakan sebagai penanda genetik yang saat ini telah berkembang pesat dan dianggap sebagai standar emas yang dapat menggambarkan keanekaragaman hayati dengan lebih baik. Keuntungan lain dari DNA mitokondria yaitu mampu mengevaluasi DNA yang terdegradasi dan bersifat informatif artinya dapat membedakan spesies vertebarata dan peninjauan terhadap keanekaragaman hayati terutama ikan (Rees et al. 2014; Freeland 2017).

Informasi yang berhasil dikumpulkan dari hasil-hasil penelitian sebelumnya menunjukkan bahwa pendekatan e-DNA menawarkan beberapa keuntungan yang jauh lebih besar dibandingkan metode tradisional dalam pemantauan keberadaan organisme target untuk pemauntauan dan konservasi keanekaragaman hayati. Hal ini disebabkan oleh kemampuan pendekatan eDNA dalam hal ketepatan dan kecepatan analisis. Pendekatan e-DNA tidak memerlukan pengkulturan dan tanda-tanda keberadaan organisme atau mikroorganisme tersebut dan semua spesies dari lingkugan dapat terdeteksi terutama spesies langka dan invasif. Dengan demikian, e-DNA dapat dijadikan suatu metode untuk pemantaun dan konservasi keanekaragaman hayati. Sehingga mitigasi ancaman spesies invasif cepat dilakukan untuk menghentikan penyebaran spesies invasif sebelum menjadi luas dan berpotensi membahayakan spesies asli.

\section{KESIMPULAN}

Hasil telusuran pustaka memperlihatkan bahwa dengan menggunakan pendekatan eDNA pemantauan dan konsevasi keanekaragaman hayati dapat dideteksi sesuai dengan taksonomi organisme dan penanda molekuler. Penanda molekuler
Cytochrome c Oxidase subunit 1 (COI) mampu mendeteksi berbagai spesies baik langka dan invasif. Dengan demikian dapat disimpulkan bahwa pendekatan e-DNA dapat dijadikan sebagai metode untuk pemantauan dan konsevasi keanekaragaman hayati pada berbagai ekosistem.

\section{DAFTAR PUSTAKA}

Aguzzi J, Chatzievangelou D, Marini S, Fanelli E, Danovaro R, et al (2019) New High-Tech Flexible Networks for the Monitoring of Deep-Sea Ecosystems. Environmental Science and Technology 53(12): 6616-6631.

Altermatt F, Little CJ, Mächler E, Wang S, Zhang X, Blackman RC (2020) Uncovering the complete biodiversity structure in spatial networks: the example of riverine systems. Oikos 129(5):1-27.

Bohmann K, Evans A, Gilbert MTP, Carvalho GR, Creer S, Knapp M, Yu DW, de Bryn M (2014) Environmental DNA for wildlifebiology and biodiversit y monitoring. Trends in Ecology \& Evolution 29(6) : 358-367.

Calderón-Sanou I, Münkemüller T, Boyer F, Zinger L, Thuiller W (2019) From environmental DNA sequences to ecological conclusions: How strong is the influence of methodological choices?. Journal of Biogeography 47(1): 193-206.

Chase JM, McGill BJ, McGlinn DJ, May F, Blowes SA, Xiao X, Knight TM, Purschke O, Gotelli NJ (2018) Embrace scale dependence to achieve a deeper understanding of biodiversity and its changes across communities. Ecology Letters 21: 1737-1751. DOI: 10.1111/ele.13151.

Cordier T, Esling P, Lejzerowicz F, Visco J, Ouadahi A, Martins C, Cedhagen T, Pawlowski J (2017) Predicting the ecological quality status of marine environments from eDNA metabarcoding data using supervised machine learning. Environmental 
Science and Technology 51(16): 91189126.

Cristescu ME, Hebert PDN (2018) Uses and misuses of environmental DNA in biodiversity science and conservation. Annual Review of Ecology, Evolution, and Systematics 49(1): 209-230.

Deiner K, Fronhofer EA, Mächler E, Walser JC, Altermatt F (2016). Environmental DNA reveals that rivers are conveyer belts of biodiversity information. Nature Communications 7(1): 1-10.

Doi H, Takahara T, Minamoto $\mathrm{T}$, Matsuhashi S, Uchii K, Yamanaka $\mathrm{H}$ (2015) Droplet digital polymerase chain reaction (PCR) outperforms real-time PCR in the detection of environmental DNA from an invasive fish species. Environmental Science and Technology 49(9): 5601-5608.

Erickson RA, Rees CB, Coulter AA, Merkes CM, McCalla SG, Touzinsky KF, Walleser L, Goforth RR, Amberg JJ (2016) Detecting the movement and spawning activity of bigheaded carps with environmental DNA. Molecular ecology resources 16(4): 957-965.

Freeland JR (2017) The importance of molecular markers and primer design when characterizing biodiversity from environmental DNA. Genome 60(4): 358-374.

Holman LE, de Bruyn M, Creer S, Carvalho G, Robidart J, Rius M (2019) Detection of introduced and resident marine species using environmental DNA metabarcoding of sediment and water. Scientific Reports 9(1):1-10.

Jackson MC, Wely OLF, Altermatt F, Durance I, Friberg N, Drumbrell AJ, Piggott JJ, Tiegs SD, Tockner K, Krug CB, Leadley PW, Woodward G (2016) Recommendations of the next generation of global freshwater biological monitoring tools. Advances in Ecological Research 55: 615-636.

Jerde CL, Chadderton WL, Mahon AR, Renshaw MA, Corush J, Budny ML, Mysorekar S, Lodge DM (2013) Detection of Asian carp DNA as part of a great lakes basin-wide surveillance program. Canadian Journal of Fisheries and Aquatic Sciences 70(4): 522-526.

Keck F, Vasselon V, Tapolczai K, Rimet F, Bouchez A (2017) Freshwater biomonitoring in the Information Age. Frontiers in Ecology and the Environment 15(5): 266-274.

Losapio G, Schöb C (2017) Resistance of plant-plant networks to biodiversity loss and secondary extinctions following simulated environmental changes. Functional Ecology 31(5): 1145-1152.

McGlinn DJ, Xiao X, May F, Gotelli NJ, Engel T, Blowes SA, Knight TM, Purschke O, Chase JM, McGill BJ (2019) Measurement of Biodiversity (MoB): A method for separating the effects of scale-dependent distribution of species abundance, density, and aggregation on diversity change. Methods in Ecology and Evolution 10(2): 258-269.

Meyer JM, Leempoel K, Losapio G, Hadly EA (2020) Molecular Ecological Network Analyses: An Effective Conservation Tool for the Assessment of Biodiversity, Trophic Interactions, and Community Structure. Frontiers in Ecology and Evolution 8:1-19.

Rees HC, Maddison BC, Middleditch DJ, Patmore JRM, Gough KC (2014) The detection of aquatic animal species using environmental DNA - a review of eDNA as a survey tool in ecology. Journal of Applied Ecology 51(5): 1450-1459.

Roslin T, Traugott M, Jonsson M, Stone GN, Creer S, Symondson WOC (2019) Introduction: special issue on species interactions, ecological networks and community dynamics - Untangling the entangled bank using molecular techniques. Molecular Ecology 28(2): 157-164.

Schallenberg L, Wood SA, Pochon X, Pearman JK (2020) What Can DNA in the Environment Tell Us About an Ecosystem?. Frontiers for Young Minds (frontiersin.org). https://kids.frontiersin.org/article/10.338 
9/frym.2019.00150 Diakses pada tanggal 2 Januari 2021.

Shu L, Ludwig A, Peng Z (2020) Standards for methods utilizing environmental dna for detection of fish species. Genes MDPI AG 11(3): 296.

Sinniger F, Pawlowski J, Harii S, Gooday AJ, Yamamoto H, Chevaldonné P, Cedhagen T, Carvalho G, Creer S (2016) Worldwide analysis of sedimentary DNA reveals major gaps in taxonomic knowledge of Deep-sea benthos. Frontiers in Marine Science 3: 1-14.

Taberlet P, Bonin A, Zinger L, Coissac E (2018) Environmental DNA: For biodiversity research and monitoring. Oxford University Press. pp 1-253.

Urban MC, Bocedi G, Hendry AP, Mihoub JB, Pe'er G, Singer A, et al (2016) Improving the forecast for biodiversity under climate change. Science 353(6304): 1-11.

Valentini A, Taberlet P, Miaud C, Civade R, Herder J, Thomsen PF et al (2016) Nextgeneration monitoring of aquatic biodiversity using environmental DNA metabarcoding. Molecular Ecology 25(4): 929-942.
Wittmann ME, Jerde CL, Howeth JG, Maher SP, Deines AM, Jenkins JA, Whitledge GW, Burbank SR, Chadderton WL, Mahon AR, Tayson J, Gantz CA, Keller RP, Drake J, Lodge DM (2014) Grass carp in the great lakes region: Establishment potential, expert perceptions, and re-evaluation of experimental evidence of ecological impact. Canadian Journal of Fisheries and Aquatic Sciences 71(7): 992-999.

Wood SA, Biessy L, Latchford JL, Zaiko A, von Ammon U, Audrezet F, Cristescu M, Pochon X (2020) Release and degradation of environmental DNA and RNA in a marine system. Science of the Total Environment 704:1-8.

Wozney KM, Wilson CC (2017) Quantitative PCR multiplexes for simultaneous multispecies detection of Asian carp eDNA. Journal of Great Lakes Research 43(4): 771-776.

Zangl L, Daill D, Schweiger S, Gassner G, Koblmüller S (2020) A reference DNA barcode library for Austrian amphibians and reptiles. PLoS ONE 15(3): 1-17.

Zhang X, Xia P, Wang P, Yang J, Baird DJ (2018) Omics Advances in Ecotoxicology. Environmental Science \& Technology 52(7): 3842-3851. 